\title{
HUBUNGAN USIA IBU HAMIL DENGAN KEJADIAN ABORTUS \\ DI WILAYAH KERJA PUSKESMAS MUNGKID \\ KABUPATEN MAGELANG TAHUN 2012
}

\author{
Yustina Ananti ${ }^{1}$, Muh. Hanafi ${ }^{2}$, CH.Sri Susilowati ${ }^{3}$ \\ ${ }^{1}$ STIKes Guna Bangsa Yogyakarta, ${ }^{2}$ Dinas Kesehatan Kabupaten Magelang, \\ ${ }^{3}$ STIKes Guna Bangsa Yogyakarta
}

\begin{abstract}
Background : Abortion is more common in women aged over 30 years and increases at the age above 35 years. There is a relationship with the incidence of maternal age abortion (miscarriage) is one of the causes of bleeding that occurs in the first and second trimesters of pregnancy.

Objective : Determine the relationship of maternal age with the incidence of abortion.

Method : This research is the type of analytical survey, using a case-control design. The number of samples in this study were 77 respondents.

Results : There are maternal age relationship with the incidence of abortion in Puskesmas Mungkid Magelang Regency in the results of the x2 count of $41.62741 .627>3.841$ (Table $\times 2$ ) and Contingency Coefficient is equal to 0.592 .
\end{abstract}

Conclutions : There are maternal age relationship with the incidence of abortion.

Keywords : Maternal age, incidence of abortion

\section{PENDAHULUAN}

Perdarahan pervagina merupakan keluhan umum yang banyak dijumpai dan merupakan penyebab cukup tinggi seorang wanita datang ke rumah sakit, terutama jika diketahui atau disangka ada kehamilan. Perdarahan pada kehamilan muda dapat disebabkan oleh bermacam-macam keadaan, tetapi yang paling sering adalah abortus (Maryunani dan Yulianingsih, 2009).

Perdarahan pervagina merupakan keluhan umum yang banyak dijumpai dan merupakan penyebab cukup tinggi seorang wanita datang ke rumah sakit, terutama jika diketahui atau disangka ada kehamilan. Perdarahan pada kehamilan muda dapat disebabkan oleh bermacam-macam keadaan, tetapi yang paling sering adalah abortus (Maryunani dan Yulianingsih, 2009).

World Health Organization (WHO) memperkirakan di seluruh dunia, dari 46 juta kelahiran pertahun terdapat 20 juta kejadian abortus. Sekitar 13\% dari jumlah total kematian istri di seluruh dunia diakibatkan oleh komplikasi abortus, 800 wanita di antaranya meninggal karena komplikasi abortus dan sekurangnya $95 \%$ di antaranya terjadi di negara berkembang (Safe Motherhood. Newsletter, 2005 dalam Handayani 2011).
Estimasi nasional menyatakan setiap tahun terjadi 2 juta kasus aborsi di Indonesia. Ini artinya terdapat 43 kasus aborsi per 100 kelahiran hidup (menurut hasil sensus penduduk tahun 2000, terdapat 53.783.717 perempuan usia 15-49 tahun) atau 37 kasus aborsi per tahun per 1.000 perempuan usia 15-49 tahun (berdasarkan Crude Birth Rate (CBR) sebesar 23 per 1.000 kelahiran hidup) (Utomo, 2001 dalam Rachman, 2011).

Angka kejadian abortus sukar ditentukan karena abortus provokatus banyak yang tidak dilaporkan, kecuali bila sudah terjadi komplikasi. Abortus spontan dan tidak jelas umur kehamilannya, hanya sedikit memberikan gejala dan tanda sehingga biasanya ibu tidak melaporkan atau berobat. Sementara itu, dari kejadian yang diketahui, $15-20 \%$ merupakan abortus spontan atau kehamilan ektopik. Sekitar 5\% dari pasangan yang mencoba hamil akan mengalami 2 keguguran yang berurutan, dan sekitar 1\% dari pasangan mengalami 3 atau lebih keguguran yang berurutan (Wiknjosastro, 2009).

Data yang diperoleh dari Dinas Kesehatan Provinsi Jawa Tengah angka kejadian komplikasi kebidanan termasuk abortus di dalamnya di Jawa Tengah pada tahun 2012 masih tinggi yaitu sebesar 125.841 atau $20 \%$ 
dari jumlah ibu hamil (Dinas Kesehatan Propinsi Jawa Tengah, 2012).

Berdasarkan data Dinkes Kabupaten Magelang tahun 2012 dari jumlah ibu hamil sebanyak 21.483 orang ditemukan sebanyak $468(2,17 \%)$ kasus abortus dengan $32(6,8 \%)$ kasus diantaranya berasal dari ibu dengan usia < 20 tahun dan > 35 tahun (Dinas Kesehatan Kabupaten Magelang, 2012).

Hasil laporan tahunan PWS-KIA puskesmas Mungkid pada tahun 2012 menyebutkan bahwa di kecamatan Mungkid dari jumlah ibu hamil 992 orang terdapat 32 $(3,23 \%)$ kasus abortus, jika dibandingkan dengan kabupaten Magelang, kejadian abortus di wilayah kerja Puskesmas Mungkid Magelang masih lebih tinggi (Puskesmas Mungkid, 2012).

Berdasarkan studi pendahuluan yang dilakukan peneliti di Puskesmas Mungkid Kabupaten Magelang pada tanggal $02-07$ September 2013 dari 10 ibu hamil yang melakukan pemeriksaan sebanyak $5(50 \%)$ merupakan ibu hamil dengan usia dibawah 20 tahun, $2(20 \%)$ ibu hamil berusia diatas 35 tahun dan dari 5 ibu hamil dengan usia dibawah 20 tahun, 1 ibu hamil diantaranya pernah mengalami abortus dan berdasarkan data PWS KIA Puskesmas Mungkid Kabupaten Magelang telah terjadi 4 kasus abortus dari bulan Januari s/d Juni 2013 dengan 1 ibu diantaranya berusia $<20$ tahun (Puskesmas Mungkid, 2013).

Berdasarkan data sekunder tersebut di atas dan hasil studi pendahuluan penulis ingin melakukan penelitian tentang - Hubungan usia ibu hamil dengan kejadian abortus di wilayah kerja Puskesmas Mungkid Kabupaten Magelang tahun 2012

\section{PEMBAHASAN}

Hasil penelitian tentang hubungan usia ibu hamil dengan kejadian abortus di wilayah kerja Puskesmas Mungkid Kabupaten Magelang Tahun 2012 adalah sebagai berikut:

1. Usia Ibu Hamil

Usia ibu hamil di wilayah kerja Puskesmas Mungkid Kabupaten Magelang tahun 2012 adalah sebagai berikut :

Tabel 1 Distribusi Frekuensi Usia Ibu Hamil di Wilayah Kerja Puskesmas Mungkid Kabupaten Magelang Tahun 2012

\begin{tabular}{llll}
\hline NO & Kategori & Frekuensi & Persentase (\%) \\
\hline 1 & Usia Beresiko $(<20$ th dan $>35$ th) & 26 & 33,8 \\
2 & Usia Tidak Beresiko (20-35 th) & 51 & 66,2 \\
\hline & JUMLAH & 77 & 100 \\
\hline
\end{tabular}

Sumber : Data Terolah, 2012

Berdasarkan tabel 1 distribusi frekuensi usia ibu hamil di wilayah kerja Puskesmas Mungkid Kabupaten Magelang tahun 2012 diperoleh hasil yaitu sebanyak 51 ibu $(66,2 \%)$ merupakan ibu dengan usia tidak berisiko (20-35 tahun). Umur atau usia adalah umur individu yang terhitung mulai saat dilahirkan sampai berulang tahun (Mubarak, 2006).

Menurut pendapat Wiknjosastro (2007) umur reproduksi aman untuk melahirkan dan persalinan adalah umur 2035 tahun, umur dibawah dan diatas usia tersebut dapat meningkatkan resiko kehamilan dan persalinan. Kematian maternal pada ibu yang berusia muda $(<20$ tahun) 2-5 kali lebih tinggi daripada usia 2029 tahun dan kematian tersebut akan meningkat kembali sesudah usia 35 tahun. Umur ibu $<20$ tahun menunjukkan rahim dan panggul ibu belum berkembang secara sempurna karena wanita pada umur ini masih dalam masa pertumbuhan sehingga panggul dan rahim masih kecil. Disamping itu, umur diatas 35 tahun cenderung mengakibatkan timbulnya masalahmasalah kesehatan seperti hipertensi, DM, anemia, TB paru dan dapat menimbulkan persalinan lama dan perdarahan pada saat persalinan serta berpotensi terjadi cacat bawaan pada janin (Hartanto, 2004).

2. Kejadian Abortus

Kejadian abortus di wilayah kerja Puskesmas Mungkid Kabupaten Magelang tahun 2012 adalah sebagai berikut :

Tabel 2 Distribusi Frekuensi Kejadian Abortus di Wilayah Kerja Puskesmas Mungkid Kabupaten Magelang Tahun 2012

\begin{tabular}{llll}
\hline No & Kategori & Frekuensi & Persentase (\%) \\
\hline 1 & Terjadi Abortus & 32 & 41,6 \\
\hline
\end{tabular}


2 Tidak Terjadi Abortus

JUMLAH

Sumber : Data Terolah, 2012

Berdasarkan tabel 2 distribusi frekuensi kejadian abortus di wilayah kerja Puskesmas Mungkid Kabupaten Magelang tahun 2012 sebagian besar ibu tidak mengalami abortus yaitu sebanyak 45 ibu $(58,4 \%)$. Menurut Sujiyatini dkk (2009) Abortus adalah ancaman atau pengeluaran hasil konsepsi pada usia kehamilan kurang dari 20 minggu atau berat janin kurang dari 500 gram. Berdasarkan hasil penelitian abortus mayoritas terjadi pada ibu dengan usia < 20 tahun. Menurut Rochjati (2003) pada primi muda rahim dan panggul ibu seringkali belum tumbuh mencapai ukuran dewasa, akibatnya diragukan keselamatan

$45 \quad 58,4$

100

dan kesehatan janin dalam kandungan. Selain itu mental ibu belum cukup dewasa sehingga diragukan ketrampilan perawatan diri dan bayinya. Bahaya yang dapat terjadi antara lain bayi lahir belum cukup bulan dan perdarahan terjadi sebelum bayi lahir.

3. Tabulasi Silang Hubungan Usia Ibu Hamil dengan Kejadian Abortus

Tabulasi silang hubungan usia ibu hamil dengan kejadian abortus di wilayah kerja Puskesmas Mungkid Kabupaten Magelang tahun 2012 secara deskriptif tertuang pada tabel dibawah ini :

Tabel 4.3. Tabulasi Silang Usia Ibu Hamil dengan Kejadian Abortus di Puskesmas Mungkid Kabupaten Magelang tahun 2012

\begin{tabular}{|c|c|c|c|c|c|c|c|}
\hline & \multirow{3}{*}{ Usia Ibu Hamil } & \multicolumn{4}{|c|}{ Kejadian Abortus } & \multirow{2}{*}{\multicolumn{2}{|c|}{ Jumlah }} \\
\hline & & \multicolumn{2}{|c|}{ Abortus } & \multicolumn{2}{|c|}{$\begin{array}{l}\text { Tidak } \\
\text { Abortus }\end{array}$} & & \\
\hline & & $f$ & $\%$ & $f$ & $\%$ & f & $\%$ \\
\hline 1 & Usia Beresiko & 24 & 92,3 & 2 & 7,7 & 26 & 100 \\
\hline 2 & Usia Tidak Beresiko & 8 & 15,7 & $4 \overline{3}$ & 84,3 & 51 & 100 \\
\hline & JUMLAH & 32 & & 45 & & 77 & \\
\hline
\end{tabular}

Sumber : Data Terolah, 2012

Hasil tabulasi silang hubungan usia ibu hamil dengan kejadian abortus diperoleh hasil yaitu pada usia ibu hamil yang berisiko sebagian besar mengalami abortus $(92,3 \%)$, sedangkan usia ibu hamil yang tidak berisiko sebagian besar tidak mengalami abortus (84,3\%).

Hasil analisis statistik antara usia ibu hamil dengan kejadian abortus di wilayah kerja Puskesmas Mungkid Kabupaten Magelang tahun 2012 dengan menggunakan uji Chi Square Test didapatkan $x 2$ hitung sebesar 41,627 maka $41,627>3,841$ (x2 Tabel), sedangkan hasil analisa statistik dengan menggunakan rumus Contingency Coefficient diperoleh hasil sebesar 0,592. Angka tersebut menggambarkan hubungan yang cukup kuat antara usia ibu hamil dengan kejadian abortus, dan hasil analisis data untuk menjawab hipotesis penelitian diperoleh dengan mencari nilai odds ratio. Hasil uji kemungkinan kejadian abortus pada ibu hamil dengan usia berisiko dengan menggunakan rumus Odd Ratio didapatkan hasil OR $=5,885$, artinya ibu hamil dengan usia berisiko akan 5,8 kali lebih besar mengalami kejadian abortus. Hasil ini sejalan dengan teori yang menyatakan bahwa usia kurang dari 20 tahun dan lebih 35 tahun merupakan usia risiko untuk hamil dan melahirkan. Usia reproduksi yang optimal bagi seorang ibu adalah $20-35$ tahun. Pada masa kurang dari 20 tahun, organ-organ reproduksi belum befungsi dengan sempurna, Rahim dan panggul ibu belum tumbuh mencapai ukuran dewasa sehingga bila terjadi kehamilan dan persalinan akan lebih mudah mengalami komplikasi dan pada usia lebih dari 35 tahun organ kandungan sudah tua sehingga mudah terjadi komplikasi. Selain itu angka kejadian kelainan kromosom akan meningkat setelah usia 35 tahun (Cunningham et all, 2006 dan Prawirohardjo, 2005).

4. Analisa Hubungan Usia Ibu Hamil dengan Kejadian Abortus

Hasil analisa hubungan usia ibu hamil dengan kejadian abortus dengan menggunakan rumus Chi Square yang dapat dilihat pada tabel berikut ini : 


\begin{tabular}{lll}
\hline $\mathbf{4 1 , 6 2 7}$ & 0,000 & 5,885 \\
\hline
\end{tabular}

\section{X2 Hitung P Value OR}

Hasil analisis statistik antara usia ibu hamil dengan kejadian abortus di wilayah kerja Puskesmas Mungkid Kabupaten Magelang tahun 2012 dengan menggunakan uji Chi Square Test didapatkan $x 2$ hitung sebesar 41,627 maka 41,627 > 3,841 (x2 Tabel).
5. Keeratan Hubungan Usia Ibu Hamil dengan Kejadian Abortus

Untuk mengetahui keeratan hubungan usia ibu hamil dengan kejadian abortus digunakan rumus Contingency Coefficient yang dapat dilihat pada tabel berikut ini :

Tabel 5 Analisa Data dengan Uji Contingency Coefficient

\begin{tabular}{ccc}
\hline Contingency & Value & Approx. Sig \\
\cline { 2 - 3 } Coefficient & .592 & .000 \\
\hline
\end{tabular}

Hasil analisa statistik dengan menggunakan rumus Contingency Coefficient diperoleh hasil sebesar 0,592. Angka tersebut menggambarkan hubungan yang cukup kuat antara usia ibu hamil dengan kejadian abortus.

6. Kemungkinan Kejadian Abortus pada lbu Hamil dengan Usia Berisiko

Analisis data untuk menjawab hipotesis penelitian diperoleh dengan mencari nilai odds ratio. Hasil uji kemungkinan kejadian abortus pada ibu hamil dengan usia berisiko dengan menggunakan rumus Odd Ratio didapatkan hasil OR $=5,885$, artinya ibu hamil dengan usia berisiko akan 5,8 kali lebih besar mengalami kejadian abortus.

\section{KESIMPULAN}

Berdasarkan hasil penelitian hubungan usia ibu hamil dengan kejadian abortus di wilayah kerja Puskesmas Mungkid Kabupaten Magelang tahun 2012 maka peneliti menyimpulkan :

1. Proporsi kejadian abortus pada usia beresiko di Puskemas Mungkid sebanyak $92,9 \%$

2. Proporsi kejadian abortus pada usia tidak beresiko di Puskesmas Mungkid 7,8 \%

3. Ada hubungan usia ibu hamil dengan kejadian abortus di wilayah kerja Puskesmas Mungkid Kabupaten Magelang tahun 2012 dengan hasil $x 2$ hitung sebesar 41,627 maka 41,627 > 3,841 (x2 Tabel).

4. Ibu hamil dengan usia berisiko akan 5,885 kali menyebabkan kejadian abortus (OR = $5,885)$
5. Ada hubungan yang cukup kuat antar usia ibu hamil dengan kejadian abortus sebesar

0,592 (berdasarkan uji Contingency Coefficient).

\section{SARAN}

Setelah peneliti melakukan penelitian tentang hubungan usia ibu hamil dengan kejadian abortus di wilayah kerja Puskesmas Mungkid Kabupaten Magelang tahun 2012, peneliti memiliki saran sebagai berikut :

1. Untuk Bidan Puskesmas Mungkid

a. Mendorong bidan Pembina wilayah supaya meyakinkan ibu hamil untuk periksa ANC secara rutin.

b. Lebih sering memberikan konseling tentang kesehatan reproduksi kepada wanita usia subur melalui pertemuan yang rutin dilaksanakan di wilayah binaannya.

2. Untuk Penelitian Selanjutnya

Hasil penelitian ini dijadikan studi pendahuluan untuk penelitian lebih lanjut.

\section{DAFTAR PUSTAKA}

Abiddin. (2011). Karakteristik Ibu Hamil yang Mengalami Abortus di RSUD Dr. Kariadi Semarang tahun $2010 . \quad$ Available from:<http://eprints.undip.ac.id/37476/1/Zanua r.pdf $>$. Accesed : 07 September 2013]

Anggiarsih. (2011). Studi Deskriptif Karakteristik lbu dengan Abortus di RSUD Banyumas 2011. Semarang : KTI D III Kebidanan Politeknik Kemenkes Semarang. 
Arikunto, S. (2006). Prosedur Penelitian Suatu Pendekatan Praktek. Jakarta : Rineka Cipta.

Budiarto, E. (2002). Biostatistika untuk kedokteran dan Kesehatan Masyarakat. Jakarta : EGC.

Cunningham. (2006). Obstetri William's. Jakarta : EGC.

Handayani. (2011). Motivasi Suami Terhadap Istri yang Mengalami Abortus di RS Dr. Pirngadi Medan. Available from : <http://repository.usu.ac.id/handle/123456789/ 27196>. [Accesed : 10 September 2013].

Harlock. (2004). Psikologi Perkembangan. Jakarta : Erlangga.

Hidayat, A.A. (2010). Metode Penelitian Kebidanan \& Teknik Analisis Data. Jakarta : Salemba Medika

Llewellyn-Jones. (2001). Dasar-Dasar Obstetri dan Ginekologi Edisi 6. Jakarta : Hipokrates.

Lusa. (2012). Abortus. Available from : <http://www.lusa.web.id/abortus/>. [Accesed : 09 September 2013].

Maryunani dan Yulianingsih. (2009). Asuhan Kegawatdaruratan dalam Kebidanan. Jakarta : Trans Info Media.

Maconochie, C. et al. (2007). Risk factors for first trimester miscarriage-results from a UKpopulation-based case-control study. BJOG.
Murphy. (2002). Early Maternal and Neonatal Morbidity Association with Operative Delivery in Second Stage of Labor aCohort Study. The Lancet Vol.358, Oktober 13, p : 1203-1207.

Notoatmodjo, S. (2010). Metode Penelitian Kesehatan. Jakarta : Rineka Cipta

Nugroho. (2012). Obsgyn Obstetri dan Ginekologi untuk Kebidanan dan Keperawatan. Jogjakarta : Nuha Medika.

Rachman. (2011). Hubungan Riwayat Trauma Terhadap Kejadian Abortus di RSUD Ulin Banjarmasin Tahun 2011. Available from : <http://ejournal.unlam.ac.id/index.php/bk/articl e/view/258>. [Accesed : 07 September 2013].

Sinaga. (2012). Hubungan Karakteristik Ibu Hamil dengan Kejadian Abortus di Puskesmas Jorlang Huluan Kecamatan Pamatang Sidamanik Kabupaten Simalungun Tahun 2012. Available from : $<$ http://uda.ac.id/jurnal/files/

Elvipson\%20Sinaga.pdf>. [Accesed : 07 September 2013].

Sugiyono. (2007). Statistika untuk Penelitian. Bandung : Alfabeta.

Sujiyatini, Mufdlilah, dan Hidayat, A. (2009). Asuhan Patologi Kebidanan. Yogyakarta : Nuha Litera Offset.

Wiknjosastro. (2009). IImu Kebidanan. Jakarta Yayasan Bina Pustaka. 